Corresponding Author:

T M Lysenko

Itm2000@mail.ru

Received: 25 October 2019

Accepted: 15 November 2019

Published: 25 November 2019

Publishing services provided by Knowledge E

(c) T M Lysenko et al. This article is distributed under the terms of the Creative Commons

Attribution License, which

permits unrestricted use and redistribution provided that the original author and source are credited.

Selection and Peer-review under the responsibility of the AgroSMART 2019 Conference Committee.

\section{Principles and Criteria of Phytocenotic Diversity Conservation (Through the Example of European Countries and Russia)}

T M Lysenko1,2, A V Ivanova², N V Kostina ${ }^{4}$, T N Davidenko4, V M Vasiukov², O N Davidenko 4 , S A Nevskii", and A A Beliachenko ${ }^{5}$

${ }^{1}$ Laboratory of general geobotany, Komarov Botanical Institute of the Russian Academy of Sciences, St. Petersburg, Russia

${ }^{2}$ Laboratory of phytodiversity, Institute of Ecology of Volga basin RAS, Togliatti, Russia

${ }^{3}$ Laboratory of modeling and ecosystem management, Institute of Ecology of Volga basin RAS, Togliatti, Russia

${ }^{4}$ Department of botany and ecology, Saratov State University, Saratov, Russia

${ }^{5}$ School of Urbanistics, Civil Engineering and Architecture Saratov State Technical University, Khvalynsky National Park, Saratov, Russia

\section{Abstract}

The article presents the review of currently existing views on the problem of phytocoenotic diversity protection in European countries and Russia. The principles and criteria for the identification of rare plant communities in need of protection, used by scientists from different countries are described. The authors had defined already published works of a monographic nature and projects, containing the information on the phytocenotic diversity of Europe in need of protection, and Green Books, published in the Russian Federation. Special attention is paid to the determination process of plant communities. It is noted that nowadays there is no single concept for the creation of Green Books. The phytocenosis protection inventories created in European countries that have a legislative basis, the Russian Green Books include vegetation monitoring data and have no legal basis.

Keywords: phytodiversity, rare plant communiies, Red Book of communities

\section{Introduction}

The conservation of the biodiversity of our planet, including the diversity of plant communities, is becoming increasingly important every decade [1]. This is reasoned by the ongoing transformation of vegetation due to the increasing anthropogenic impact and climate change on a global scale.

Recently, European countries have been actively developing the "Red book of plant communities" (in Russian they are "Green Books of Plant Communities"), which are aimed at the identification of communities in need of protection, which are the habitat of 
within the community, and it can be preserved only there. The founder of the theoretical developments of this direction is E.M. Lavrenko, who believed that the presence of rare species, especially in the status of dominants and codominants, is one of the criteria for the protection of communities. In addition, it is necessary to preserve zonal (typical) communities and phytocenoses located on the border of their ranges.

The conservation of existing plant communities ensures the functioning of the biosphere as a whole. This is one of the principles of the ecosystem approach.

\section{Methods and Materials}

The article presents an overview of currently existing views on the problem of phytocenotic diversity protection in European countries and the Russian Federation, as well as the principles and criteria for the identification of rare plant communities in need of protection.

\section{Results}

Great work has been done in European countries on the conservation of phytocenotic diversity over the past half century. Back in the $70 \mathrm{~s}$ of the $20^{\text {th }}$ century, the first approaches were published in the scientific literature of Germany, which later became widely developed. Initially, rare and vulnerable plant communities were considered on the territory of individual federal lands. The Index and the Red List of Plant Communities [2] summarized material throughout Germany and presented information on 807 rare associations and communities in need of protection. In the 1980 s, books about plant communities in need of protection appeared in the Czech Republic [3] and Ukraine [4]. The 90 s of the $20^{\text {th }}$ century were marked by a wide coverage of the problem of phytocenotic diversity conservation in the scientific literature of Estonia [5], Austria [6], Switzerland [7] and Russia [8]. At the beginning of the $21^{\text {st }}$ century, the monographs on rare plant communities in Eastern Europe [9] and various regions of Russia [10--13] began to be developed.

Let us consider the development of views on the principles and criteria for the identification of rare plant communities in need of protection and the creation of relevant Green Books.

On the basis of the use of floristic, botanical-geographical, phytocenotic and other criteria of conservation value, S.M. Stoyko [14] identified 7 categories of communities in need of protection. Later, this division of phytocenoses was taken into account in 
order to develop principles for the identification of rare, endangered and typical plant communities when creating the Green Book of the Ukrainian SSR [4]. The $1^{\text {st }}$ category includes phytocenoses, the edifiers and co-edifiers of which are high-grade taxons listed in the Red Books. They are characterized by instability during the succession and a tendency to reduce the area. The $2^{\text {nd }}$ category combines indigenous phytocenoses, formed by the same species, but distinguished by their stability during succession and the stability of the range. Indigenous communities belong to the $3^{r d}$ category, in which various phytocenotic positions are occupied by common species, but with reduced ecological and biological potential at the boundary of the range or altitude distribution, as well as intrazonal phytocenoses deserving protection by botanical-geographical or chorological characteristics. The $4^{\text {th }}$ category combines phytocenoses ecologically associated with endangered representatives of animal world. The $5^{\text {th }}$ category includes indigenous phytocenoses with rare combinations of phytocenotypes, but presenting phytocenotic or economic interest, as well as phytocenoses of scientific research or economic reference value. The $6^{\text {th }}$ category includes the culture-phytocenoses from promising introduced or aboriginal species that have experimental or reference value. The $7^{\text {th }}$ category combines phytocenoses, previously widespread, but which became rare as a result, not so much due to natural historical causes, but to industrial or natural fires.

In 2009, the second issue of the Green Book of Ukraine [9] was published, which is an official government document, containing information on the current state of rare, endangered, and typical natural plant communities in need of protection. The "Regulation on the Green Book of Ukraine" was approved by a resolution of the Ministry of Ukraine in August 29, 2002, and the methodology for establishing the environmental status of communities was approved by order of the Ministry of Conservation and Environmental Management of Ukraine in May 27, 2009. The Green Book of Ukraine is the basis for the development of conservation measures, reproduction and use of plant communities recorded in it. In the European Union countries, NATURA 2000 project has been implemented. It is a network of territories where protection of certain species of animals and plants and their habitats is required. The legal basis for the NATURA 2000 project is the Directive 79/409 / of Council of the European Union, of April 2, 1979 on the protection of wild birds, as well as Directive 92/43 / of May 21, 1992 on the protection of natural habitats and wild birds, fauna and flora. The legal regulations of the project list the species of animals and plants that, due to their rarity and requirements for habitat conditions, especially need to be protected. This, first of all, refers to species and their ranges that are under threat of extinction. According to the proposal of the 
States Parties, specific areas are identified for the protection of these species and their ranges.

The regions are divided into 7 biogeographic regions of the European Union -- Alpine, Atlantic, Polar, Continental, Macaroesian, Mediterranean and Pannonian. The NATURA 2000 network includes protected areas where conservation of more than 180 species and subspecies of birds should be ensured, as well as special reserves in which more than 250 different habitats, more than 200 species of animals and more than 430 plant species are to be preserved. Nowadays NATURA 2000 includes more than $20 \%$ of the territory of the European Union. The States Parties are responsible for protected areas and must ensure the safety of species and their ranges defined by legal regulations.

Within these territories, economic activity, such as agricultural, are still allowed, but it should comply with the purpose of the conservation of the species and their habitats.

In addition, in European countries, a project of the organization of Key Botanical Territories in order to protect the most valuable botanically protected sites is being developed $[15,16]$.

Most recently, the European Union completed a major project "Red List of Habitats of Europe", which led to the publication of the results in two parts: the first part includes lists of marine habitats [17], the second part -- terrestrial and freshwater habitats [18].

For the present period in the Russian Federation, the "Green Books of Plant Communities" are created for only a few regions. In 1996, the Green Book of Siberia [8] was published. It used the following principles and criteria for identifying rare plant communities in need of protection: 1) scientific significance; 2) communities as a habitat of species; 3) resource significance. This book uses an ecological-phytocenotic approach to the classification of vegetation, 196 protection units were found: 51 of which are steppe communities, 46 are forest, 33 are tundra, 18 are marsh, 10 are meadow, 20 are flood plain and 5 are halophyte.

In 1997, the "Red Book of Plant Communities of the Former USSR" [19] was published, which presented a list of rare syntaxon in need of protection. It uses an ecologicalfloristic approach to the classification of vegetation.

Ufa scientists [10] consider the ecological-floristic classification of vegetation to be one of the effective bases for the protection of vegetation and the creation of specially protected natural areas, since it is based on the analysis of complete floristic lists and allows evaluating the distribution of rare, endemic and relict species, and also establishing thin floristic and ecological differences between phytocenoses. The syntaxons determined on the basis of using this approach have a clear ecological characterization 
and can be rather easily transformed into typological units used in nature conservation, forest and grassland practices.

On the basis of the analysis and generalization of the experience of international and Russian researchers in the Laboratory of geobotany and vegetation protection of Institute of Biology of Ufa Scientific Center of Russian Academy of Sciences (IB USC RAS), a set of essential characteristics was proposed and scales to assess the conservation value of plant communities were developed. The system implies that communities receive expert evaluation based on 6 criteria: 1) floristic-phytocenotic significance; 2) rarity; 3) naturalness; 4) reduction of occupied area; 5) recoverability; 6) protection provision. The use of these criteria leads to two integral indicators that determine the conservation status of plant communities: 1) danger of extinction; 2) category of protection.

The assessment of the risk of extinction is carried out taking into account the type of rarity, reduction of occupied area, ability to recover, protection provision, and presence of threatening factors. To assess the status of rare species, the IUCN scale [20] is used: Ex -- extinct, EW -- extinct in the wild, Cr -- critically endangered, En -- endangered, Vu -vulnerable, LR -- lower risk, DD -- data deficient -- species for which there is insufficient data.

The category of protection reflects the value of the plant community and is defined as an integral indicator of the following parameters: 1) floristic-phytocenotic significance; 2) the nature of the distribution; 3) naturalness; 4) reduction of occupied area. A 4-grade rating scale was used: highest, high, medium, low. After determining the category of plant community protection, it is proposed to assess the status of the protected area as a derivative of the protection categories of all communities in a certain territory.

V.A. Glazunov [21] developed a system for the assessment of the conservation value of the plant communities of the forest-steppe zone of the Tyumen Region, taking into account regional characteristics of the research area: 1) the complete absence of endemic and very small number of relict species of the flora, which have virtually no effect on the degree of floristic significance for most communities; 2) finding a significant number of species, including dominants and codominants, on the border of their distribution, which determines the floristic and phytocenotic significance of most communities; 3) a unique combination of species in communities with European and Asian types of habitat, due to geographic location.

In 2006, the Green Book of the Samara Region was published [11], which used the following criteria: 1) scientific significance; 2 ) the nature of the placement of communities in the syntaxon range (rare); 3) the conservation status of communities; 4) the parameters 
of biodiversity and structural phytocenotic features of the community as a habitat for species; 5 ) the categories of the current state of community protection and the required status.

The Green Book of the Samara Region is based on the ecological-phytocenotic approach to the classification of vegetation, but in many cases, when characterizing protection units, alliances, orders and classes are indicated in accordance with the ecological-floristic approach. In total, 87 units of protection were determined for the Samara region: 51 are steppe communities, 13 are forest, 9 are halophyte, 9 are waterside and water, and 5 are rocky. The passports (sketches) of plant communities were composed.

When creating the Green Book of the Bryansk Region (plant communities in need of protection), Bryansk botanists [12] conducted a comparative analysis of existing approaches and created a point scale for the determination of conservation status of plant communities, in which expert indicators are grouped into 4 blocks: 1) R -- rarity; 2) G -- special characteristics of communities, including such expert indicators as the ecological amplitude of a community; the ability to recover; naturalness; resistance to anthropogenic effects; 3) $\vee$-- the value of communities in nature and human activities; 4) $P$-- territorial protection. The conservation status is calculated by the equation given by the authors as the total amount of points. The Green Book of the Bryansk Region used an ecological-floristic. The book includes 45 types of plant communities, including 33 types of rare communities, 7 reference communities, 5 rare communities and 61 bryophytes. The types of plant communities are attributed to 39 associations, 4 subassociations and 2 unranked communities of 17 classes of vegetation. The passports (sketches) of plant communities were composed.

In 2018, the "Green Book of the Saratov Region: Plant communities in need of protection" was published [13]. The book used the dominant determinant principle. For the phytocenoses offered for protection, a scale of categories and rarity statuses was adopted: 1 (E) -- (exceptional) unique phytocenoses, 1--2 known points, for the conservation of which it is expedient to organize specially protected natural territories; 2 (R) -- (rare plants communities) truly rare phytocenoses, 3--5 points known for a region; 3 $(H)$-- (habitat of rare plant species) communities with the participation of protected plant species, which show loyalty to this particular phytocenosis, and communities dominated by protected plant species; 4 (S) -- (standart) phytocenoses of interest in the context of reference for the region, with minimal anthropogenic disturbances and a complex structure. In total, 19 steppe, 16 halophytic, 11 forest, 8 water and 8 communities of 
carbonate habitats were recommended for protection on the territory of the Saratov region.

\section{Conclusion}

Nowadays a unified concept of the creation of "Red" or "Green" books of rare plant communities that are in need of protection is not formed. In European countries, existing inventories of phytocenosis needing protection have a legislative basis. In Russia, the Green Books of the regions include vegetation monitoring data and do not have a legislative basis. The results of studies of rare plant communities presented in them can be used in the design and creation of ecological networks, individual protected areas, zoning in national and natural parks.

\section{Acknowledgment}

The research was conducted in the framework of AAAA-A17-117071760037-0 state order of Komarov Botanical Institute of the Russian Academy of Sciences, and AAAA-A17117112040040-3 state order of Institute of Ecology of Volga basin of Russian Academy of Science.The authors express gratitude to Russian Foundation for Basic Research for partial financial support for research (grant project No. 16-04-00747a).

\section{References}

[1] Cardinale, B.J., Duffy, J.E., Gonzalez, A. et al. (June 2012). Biodiversity loss and its impact on humanity. Nature, vol. 486, pp. 59--67.

[2] Rennwald, E. (2000). Verzeichnis, Rote Liste der Pflanzengesellschaften Deutschlands. Bonn: Schriftreihe für Vegetationskunde, H. 35, 810 p.

[3] Moravec, J., Balátová-Tuláčková, E., Hadač, E. et al. (1983). Rostlinná společenstva České socialistické republiky a jejich ohrožení, vol. 1. Příl: Severočeskou Přír, 110 p.

[4] Green Book of the Ukrainian SSR: rare, endangered and typical plant communities in need of protection. (1987). Kiev: Naukova Dumka, 214 p.

[5] Paal, J. (1998). Rare and threatened plant communities of Estonia. Biodiversity and Conservation, vol. 7, pp. 1027--1049.

[6] Wittmann, H., Strobl, W. (1990). Gefährdete Biotypen und Pflanzengesellschaften in Salzburg -- Ein erster Überblick. Naturschutzbeiträge, H. 9, pp. 1--81. 
[7] Steiger, P., Mitwirk, u., Carraro, von G., Frey, H.-U., Frick, A. (1998). Wälder der Schweiz. Von Lindegrün zu Lärchengold. Vielfalt der Waldbilder und waldgesellschaften in der Schweiz, 3rd ed. Thun: Ott Verlag, 361 p.

[8] Siberian Green Book: rare and plant communities in need of protection. (1996). Novosibirsk: Nauka, 396 p.

[9] Green Book of Ukraine. (2009). Kyiv, 448 p.

[10] Martynenko, V.B., Mirkin, B.M. (2003). On formal and informal assessments of floristic diversity (on the example of the pine forests of the Southern Urals). Ecology, vol. 5.

[11] The Green Book of the Samara Region: rare and protected plant communities. (2006). Samara: SamSC of RAS, $201 \mathrm{p}$.

[12] Green Book of the Bryansk Region (plant communities in need of protection). (2012). Bryansk: State Unitary Enterprise Bryansk. region polygons Association, $144 \mathrm{p}$.

[13] Green Book of the Saratov Region: plant communities in need of protection. (2018). Saratov: Amirit, $133 \mathrm{p}$.

[14] Stoyko, S.M. (1983). Ecological bases of protection of rare, unique and typical plant communities. Botanical Journal, vol. 68(11), pp. 1574--1583.

[15] European Security Strategy -- A Safe Europe in a Better World. Luxembourg: Office for Official Publications of the European Communities, 2009, $43 \mathrm{p}$.

[16] Key Botanical Territories of Northern Eurasia: collection of articles, iss. 1. Moscow: Publishing House of the World Conservation Union (IUCN) for Russia and CIS countries, 2004, $75 \mathrm{p}$.

[17] Gubbay, S. et al. (2016). European Red List of Habitats, Part 1. Marine habitats. Luxembourg: Publications Office of the European Union, 52 p. doi: 10.2779/032638.

[18] Janssen, J.A.M. et al. (2016). European Red List of Habitats, Part 2. Terrestrial and freshwater habitats. Luxembourg: Publications Office of the European Union, $44 \mathrm{p}$. doi: 10.2779/091372.

[19] Solomeshch, A., Mirkin, B., Ermakov, N. et al. (1997). Red data book of plant communities in the former USSR. Birmingham: Templar Print \& Design Ltd., 70 p.

[20] IUCN red List Categories. (1994). Prepared by the IUCN Species Survival Commission. As approved by the 40th Meeting of the IUCN Council Switzerland, 30 November 1994). Glandl Published by IUCN, pp. 1--21.

[21] Glazunov, V.A. (2003). Principles of allocation and categories of rare species and plant communities in the contact zones of biogeographic zones (for example, the territory of the forest-steppe south of the Tyumen region). Advances in modern science, vol. 11, pp. 139--140. 